\title{
Purification and Properties of an Aminopeptidase from Rabbit Skeletal Muscle
}

\author{
Yuzuru Otsuka, Akihiro Okitani, Ryoichi Katakai* \\ and Masao FuJmaki \\ Department of Agricultural Chemistry, University of Tokyo, Tokyo \\ * Department of Industrial Chemistry, College of Technology, \\ Gunma University, Gunma
}

Received May 20, 1976

\begin{abstract}
An aminopeptidase active on L-Val-L-Val-L-Val-L-Ala was purified from rabbit skeletal muscle by the method including ammonium sulfate precipitation, DEAE-cellulose chromatography, gel-filtration on Sephadex G-200, rechromatography on DEAE-cellulose, hydroxylapatite chromatography and rechromatography on Sephadex G-200. Polyacrylamide gel disc electrophoresis showed that the enzyme thus obtained was homogeneous. The specific activity of the purified enzyme was 1500 times that of the original muscle extract. The enzyme had an optimal $\mathrm{pH}$ in a range of 6.0 7.6 and was stable in $\mathrm{pH} 6.1 \sim 8.1$. Molecular weight of the enzyme was estimated to be 160,000 from the result of gel-filtration on Sephadex G-200. The enzyme showed specificity for tri-, tetra-, penta-, and hexapeptides. The analytical data of liberated amino acids showed that the enzyme was an aminopeptidase active on these oligopeptides. The enzyme was strongly inhibited by $N$-ethyl-maleimide and EDTA.
\end{abstract}

We have been studying on the proteolysis in rabbit skeletal muscle. ${ }^{1 \sim 3\}}$ In our recent paper, ${ }^{3)}$ we found that, besides an acidic proteolytic system consisting of cathepsins, there was another proteolytic system active in a neutral $\mathrm{pH}$ region, and it was constituted of various proteinases and peptidases.

It is well known that various kinds of peptidases are present in animal tissues to hydrolyze oligopeptides. ${ }^{4}$ It is, however, not yet certain that these peptidases contribute to the hydrolysis of tetrapeptides or larger oligopeptides in animal tissues. Ellis and Perry, ${ }^{5>}$ Auricchio et al., ${ }^{6)}$ and Donlon and Fottrell ${ }^{7}$ have reported the presence of a tetrapeptide hydrolysis activity in tissues. However, they have not purified and not examined the properties of the enzyme in detail. Thus, there are only a few reports made so far on the proteases which hydrolyze such oligopeptides. The mechanism of the oligopeptide hydrolysis in tissues seems

** The following abbreviations are used: VVVA, Val-Val-Val-Ala; EDTA, ethylenediaminetetraacetic acid; NEM, $N$-ethylmaleimid; IAA, monoiodoacetic acid; DTT, dithiothreitol; DIPF, diisopropylphosphofluoridate. to be also unknown.

In the present paper, $* *$ we describe the methods for the purification and the properties of a muscle aminopeptidase that hydrolyzes tri-, tetra-, penta-, and hexapeptides. For the purification we employ a synthetic oligopeptide, VVVA, as substrate for convenience, although this aminopeptidase can hydrolyze also other various oligopeptides.

\section{MATERIALS AND METHODS}

Muscles. The muscle (longissimus dorsi) of rabbit was obtained from the carcass immediately after slaughter and minced with a meat chopper.

Chemicals. VVVA, Gly-Gly-Ile-Ala, Lys-Gly-IleAla, Thr-Gly-Ile-Ala, Ile-Gly-Ile-Ala, Glu-Gly-Ile-Ala, D-Ala-Gly-Ile-Ala, Ala-Gly-Phe-Ala, Met-Gly-Phe-Ala, Val-Gly-Phe-Ala and Ala-Leu-Gly-Ala-Leu-Gly were synthesized by the methods reported by Katakai. ${ }^{8)}$ $\mathrm{Gly}_{2}$, Gly $\mathrm{y}_{3}$, Z-Gly-Phe, Val-Tyr-Val, and Gly-Leu-Tyr were obtained from Protein Research Foundation, Osaka, $\mathrm{Val}_{5}, \mathrm{Val}_{3}, \mathrm{Val}_{4}$ and $\mathrm{Val}_{5}$ were from Bachem Inc., California, Ile-Gly, Leu-Gly, Val-Gly, His-Gly, Ser-Gly, Phe-Gly, Thr-Gly, Tyr-Gly and Met-Gly were from Cyclo Chemical Co., California. The peptides other than D-Ala-Gly-Ile-Ala, were all 
constituted of L-amino acids. DEAE-cellulose was obtained from Brown Co. and Whatmann Co. (DE-52), hydroxylapatite from Seikagaku-Kogyo, Japan, calibration proteins from Boehringer-Mannheim-Japan, Japan. All other chemicals were of guaranteed reagent grade.

Assay, One-fifth milliliter of enzyme in $0.01 \mathrm{M}$ trisHCl buffer ( $\mathrm{pH} 7.2$ ) containing $4 \mathrm{~mm} 2$-mercaptoethanol was preincubated for $3 \mathrm{~min}$ and incubated with $0.2 \mathrm{ml}$ of $1 \mathrm{~mm}$ substrate in $0.01 \mathrm{M}$ Tris- $\mathrm{HCl}$ buffer $(\mathrm{pH} 7.2$ ) at $37^{\circ} \mathrm{C}$ for $20 \mathrm{~min}$. The incubation was stopped by adding $2.0 \mathrm{ml}$ of cold $2.0 \mathrm{M}$ citrate buffer (pH 5.0 ). After $1.6 \mathrm{ml}$ of the ninhydrin reagent ${ }^{\theta>}$ were added to the reaction mixture, the whole mixture was boiled at $100^{\circ} \mathrm{C}$ for $15 \mathrm{~min}$ and then cooled in running water. The optical density was measured at $570 \mathrm{~nm}$. The enzyme activity was expressed as follows: one unit= an amount of the enzyme which produces one $\mu$ mole amino acid per min at $37^{\circ} \mathrm{C}$. The production of amino acid during the incubation was measured by the ninhydrin method described above.

Protein concentration. Optical densities were measured at $260 \mathrm{~nm}$ and $280 \mathrm{~nm}$ with a Hitachi Spectrophotometer (EPS-3T), and a protein concentration was calculated by the method of Layne. ${ }^{10}$ )

\section{RESULTS}

\section{Purification of the enzyme}

Step 1) Extraction and ammonium sulfate precipitation. All the procedures were performed at $4^{\circ} \mathrm{C}$. Minced muscle $(1100 \mathrm{~g})$ was added to $3300 \mathrm{ml}$ of $0.04 \mathrm{M}$ Tris-HCl buffer (pH 7.2) and homogenized with a Waring blender for $1 \mathrm{~min}$. The homogenate was centrifuged at $4500 \times g$ for $15 \mathrm{~min}$. To the supernatant (crude extract) were added 2mercaptoethanol up to $4 \mathrm{~mm}$ and ammonium sulfate up to $55 \%$ saturation. The mixture was centrifuged at $4500 \times g$ for $15 \mathrm{~min}$. Ammonium sulfate was added again to the supernatant up to $75 \%$ saturation, and then centrifuged. The precipitate was collected and dissolved in $0.01 \mathrm{M}$ Tris- $\mathrm{HCl}$ buffer $(\mathrm{pH} \mathrm{7.2)} \mathrm{con-}$ taining $4 \mathrm{~mm}$ 2-mercaptoethanol, and it was dialyzed against the same buffer to obtain an ammonium sulfate precipitate fraction.

Step 2) DEAE-cellulose column chromatography. The ammonium sulfate precipitate fraction $(480 \mathrm{ml})$ was applied to a DEAEcellulose (Brown Co.) column $(4.5 \times 30 \mathrm{~cm})$ previously equilibrated with $0.01 \mathrm{M}$ Tris- $\mathrm{HCl}$ buffer ( $\mathrm{pH} \mathrm{7.2)} \mathrm{containing} 4 \mathrm{~mm}$ 2-mercaptoethanol. After the column was washed upto tube No. 20 with the same buffer, the enzyme was eluted with a linear gradient of increasing concentration of sodium chloride from 0 to $0.4 \mathrm{M}$ in the same buffer (Fig. 1). The eluate was collected in $20-\mathrm{ml}$ fractions. The fractions from No. 98 to No. 103 were pooled.

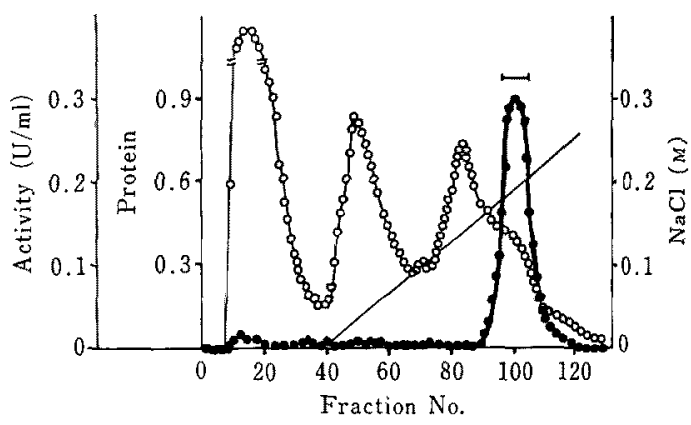

FIG. 1. Chromatography of the Ammonium Sulfate Precipitate Fraction on DEAE-cellulose.

The peak fractions from No.98 to No. 103 were pooled. - - VVVA hydrolysis activity; $\mathrm{O}-\mathrm{O}$, protein (O.D.250); - $\mathrm{NaCl}$.

Step 3) Gel-filtration on Sephadex G-200. The enzyme $(120 \mathrm{ml})$ eluted from the DEAEcellulose column was concentrated with a membrane filtration apparatus (Diafilter 10-T), and subjected to the gel-filtration on a Sephadex G-200 column $(1.5 \times 120 \mathrm{~cm})$ previously equilibrated with $0.01 \mathrm{M}$ Tris-HCl buffer $(\mathrm{pH} 7.2)$

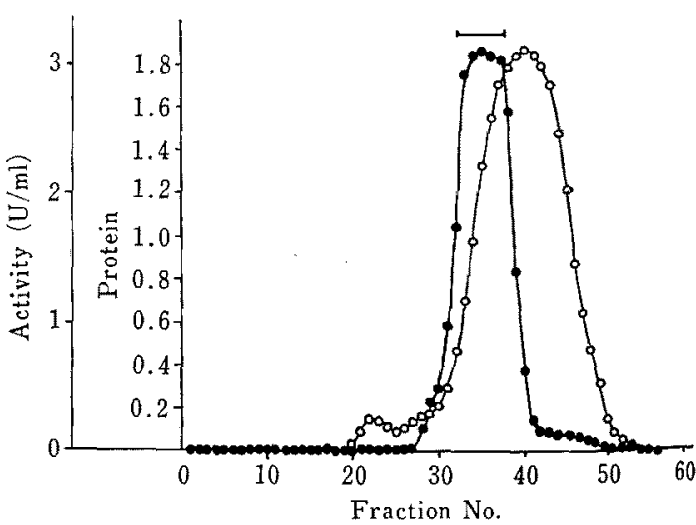

FIG. 2. Gel Filtration on Sephadex G-200.

The peak fractions from No. 33 to No. 38 were pooled. -- VVVA hydrolysis activity; $\mathrm{O}-\mathrm{O}$, protein (O.D. ${ }_{280}$ ). 
containing $4 \mathrm{~mm}$ 2-mercaptoethanol. Filtration was performed with the same buffer, and flow rate was $5 \mathrm{ml} / \mathrm{hr}$. The eluate was collected in 3-ml fractions. The result is shown in Fig. 2. The fractions from No. 33 to No. 38 were pooled.

Step 4) Rechromatography on DEAE-collulose. The enzyme $(18 \mathrm{ml})$ eluted from the gel-filtration was applied to a DEAE-cellulose (Whatman DE-52) column $(1.5 \times 30 \mathrm{~cm})$. The elution was carried out with a linear gradient of increasing concentration of sodium chloride from 0 to $0.4 \mathrm{M}$ in the same buffer, and the eluate was collected in 3-ml fractions. The result is shown in Fig. 3. The fractions from No. 55 to No. 60 were pooled.

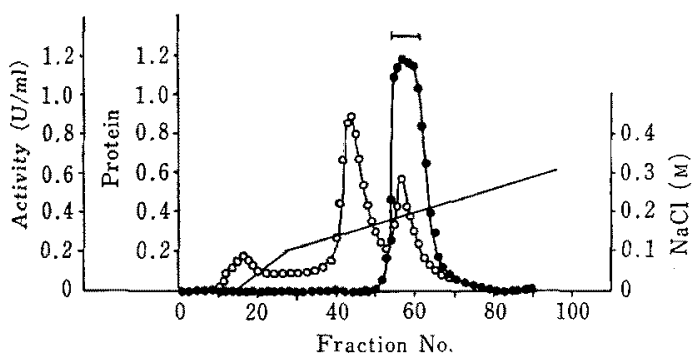

FIG. 3. Rechromatography on DEAE-cellulose (Whatman DE-52).

The fractions from No. 55 to No. 60 were pooled.

-0 VVVA hydrolysis activity; $0-0$, protein (O.D.290);, $\mathrm{NaCl}$.

Step 5) Hydroxylapatite column chromatography. The enzyme $(23.7 \mathrm{ml})$ eluted from the DEAE-cellulose column was dialyzed against $1 \mathrm{~mm}$ potasium phosphate buffer (pH 7.2) containing $4 \mathrm{~mm}$ 2-mercaptoethanol, and subjected to a hydroxylapatite column $(0.9 \times 5.5 \mathrm{~cm})$ previously equilibrated with the same buffer. After the column had been washed with the same buffer, the elution was made in a step-wise manner with $0.03 \mathrm{M}, 0.04 \mathrm{M}$, $0.08 \mathrm{M}, 0.10 \mathrm{M}$ and $0.15 \mathrm{M}$ potasium phosphate buffers ( $\mathrm{pH} 7.2$ ) all containing $4 \mathrm{~mm}$ 2-mercaptoethanol. The eluate was collected in 3-ml fractions. The result is shown in Fig. 4. The fractions from No. 11 to No. 13 were pooled.

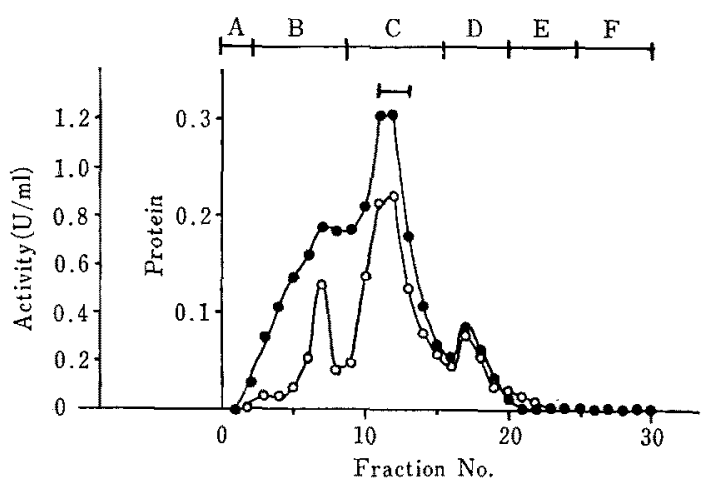

FIG. 4. Hydroxylapatite Column Chromatography. $\mathrm{A}, \mathrm{B}, \mathrm{C}, \mathrm{D}, \mathrm{E}$ and $\mathrm{F}$; respectively $0.001 \mathrm{M}, 0.03 \mathrm{M}$, $0.04 \mathrm{M}, 0.08 \mathrm{M}, 0.10 \mathrm{M}$ and $0.15 \mathrm{M}$ potassium phosphate buffer ( $\mathrm{pH}$ 7.2) containing $4 \mathrm{~mm}$ 2-mercaptoethanol. - - VVVA hydrolysis activity; $0-0$, protein (O.D.250).

Step 6) Rechromatography on Sephadex $G-200$. The enzyme $(15 \mathrm{ml})$ eluted from the hydroxylapatite column was dialyzed against $0.01 \mathrm{M}$ Tris- $\mathrm{HCl}$ buffer ( $\mathrm{pH} 7.2$ ) containing $4 \mathrm{~mm} 2$-mercaptoethanol. The dialyzed enzyme was concentrated with a membrane filtration apparatus, and subjected to the gel-filtration on a Sephadex G-200 column $(1.5 \times 120 \mathrm{~cm})$ previously equilibrated with $0.01 \mathrm{M}$ Tris $-\mathrm{HCl}$ buffer ( $\mathrm{pH} 7.2$ ) containing $4 \mathrm{~mm}$ 2-mercaptoethanol. The filtration was performed with the same buffer at a flow rate of $5 \mathrm{ml} / \mathrm{hr}$, and $3-\mathrm{ml}$ fractions were collected. The result is shown in Fig. 5. The fraction No. 31 was used as a main enzyme fraction. The results obtained through the purification process are summarized in Table I. The enzyme was purified about 1500 -folds, with a recovery of

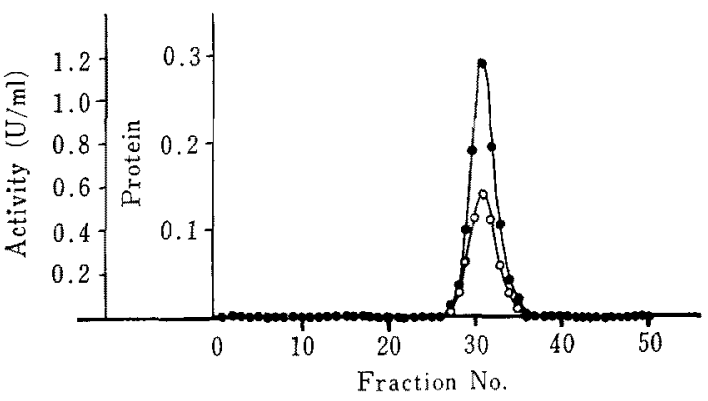

FIG. 5. Rechromatography on Sephadex G-200.

-.-., VVVA hydrolysis activity; $\mathrm{O}-\mathrm{O}$, protein (O.D.290). 
Table I. Purification of Rabit Muscle AMINOPEPTIDASE

\begin{tabular}{lcc}
\hline \multicolumn{1}{c}{ Fraction } & $\begin{array}{c}\text { Specific activity } \\
\text { (units/mg protein) }\end{array}$ & $\begin{array}{c}\text { Recovery } \\
(\%)\end{array}$ \\
\hline Crude extract & 0.005 & 100 \\
$55 \% \sim 75 \%\left(\mathrm{NH}_{4}\right)_{2} \mathrm{SO}_{4}$ & 0.022 & 172 \\
precipitate & 0.649 & 19 \\
DEAE-cellulose & 1.1 .84 & 14 \\
Sephadex G-200 & 2.450 & 6.7 \\
2nd DEAE-cellulose & 4.111 & 5.0 \\
Hydroxylapatite & 7.338 & 1.3 \\
2nd Sephadex G-200 & & \\
\hline
\end{tabular}

a) Calculated on the pooled fractions.

$1.3 \%$, over the crude extract.

\section{Purity}

The purity of the purified enzyme was detected by the polyacrylamide gel disc electrophoresis as described by Davis ${ }^{11}$ with $7.5 \%$ acrylamide gel at $\mathrm{pH}$ 8.4. Riboflavin was used instead of ammonium persulfate to initiate polymerization. After the electrophoresis had been made, protein was stained with amidoblack $10 \mathrm{~B}$ and was traced in a densitometer (Gilford Spectrophotometer 240). As shown

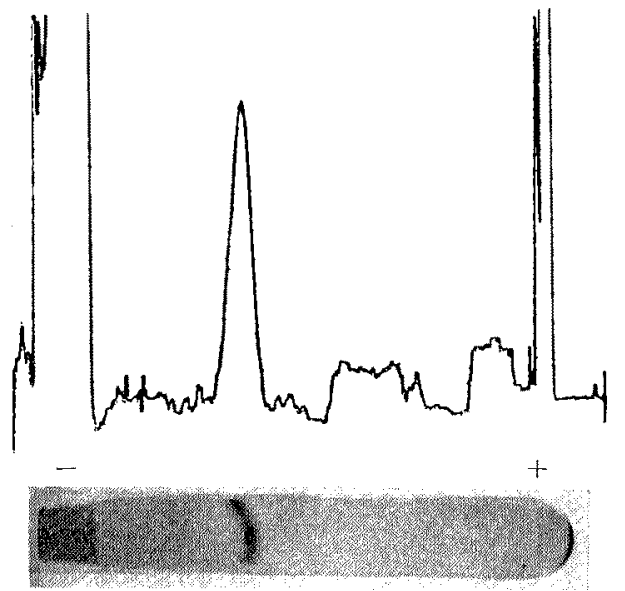

Frg. 6. Acrylamide Gel Disc Electrophoresis of the Purified Enzyme.

Electrophoresis was performed at $20^{\circ} \mathrm{C}$ and $0^{\circ} \mathrm{C}$ at pH 8.4 by the method of Davis. ${ }^{11)}$ Riboflavin was used for gel formation, and 2-mercaptoethanol was added into the gel (a final concentration of $4 \mathrm{~mm}$ ). The protein $(20 \mu \mathrm{g})$ was added, and an electric current of $5 \mathrm{~mA} / \mathrm{gel}$ was applied. After the electrophoresis, protein was stained with amidoblack 10B, and the protein band was traced in a densitometer (Gilford spectrophotometer 240 ). in Fig. 6, a single peak was detected and the enzyme activity was detected at the same position.

\section{Molecular weight}

Molecular weight of the enzyme was determined in the gel-filtration on Sephadex G-200 (Fig. 5). Ferritin, catalase, aldolase, bovine serum albumin, hen egg albumin and cytochrome-c were used as marker proteins. As shown in Fig. 7, the molecular weight was estimated to be 160,000 .

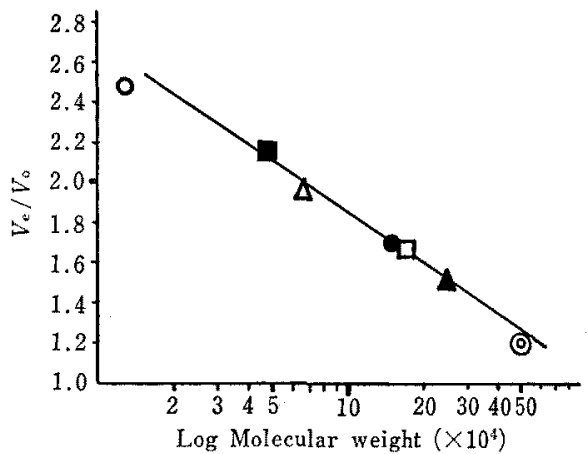

FIG. 7. Molecular Weight Determination of the Enzyme.

Molecular weight of the enzyme was determined on a Sephadex G-200 column $(1.5 \times 120 \mathrm{~cm})$. Molecular weight was estimated to be 160,000 . (), ferritin; $\Delta$, catalase; $\square$, aldolase; $\Delta$, bovine serum albumin; $\mathbf{E}$, hen egg albumin; $O$, cytochrome-c; $\boldsymbol{\bullet}$, the enzyme.

Effect of $\mathrm{pH}$ on the enzyme activity and stability The optimal $\mathrm{pH}$ for the enzyme activity was determined using the buffers in a $\mathrm{pH}$ range from 5.3 to 8.4. As shown in Fig. 8, the enzyme was most active between $\mathrm{pH} 6.0$ and 7.6. The enzyme was fairly stable between $\mathrm{pH} 6.1$ and 8.1 at $37^{\circ} \mathrm{C}$ in the buffers of a $\mathrm{pH}$ range from 3.2 to 8.1 (Fig. 9).

Effect of temperature on the enzyme activity and stability

As shown in Figs. 10 and 11, the optimal temperature was approximately $37^{\circ} \mathrm{C}$ and the enzyme was more stable at lower temperatures.

\section{Effect of metal ions on the enzyme activity}

Effect of various metal ions on the enzyme activity was checked. The results are shown 


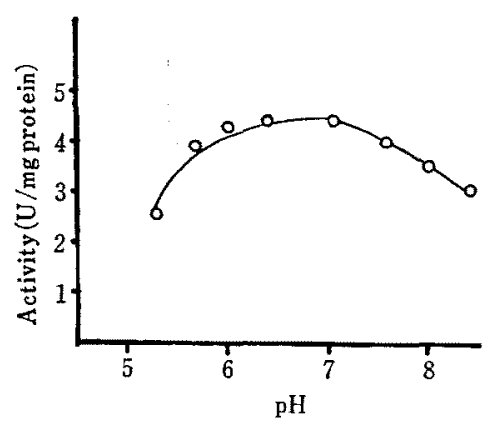

Fig. 8. Effect of $\mathrm{pH}$ on the Enzyme Activity.

Assay: One-fifth $\mathrm{ml}$ of $1 \mathrm{~mm}$ VVVA in Tris- $\mathrm{HCl}$ buffer (pH 7.2) was incubated with $1.26 \mu \mathrm{g}$ of the purified enzyme in $0.025 \mathrm{ml}$ of $0.01 \mathrm{M}$ Tris- $\mathrm{HCl}$ buffer (pH 7.2) containing $4 \mathrm{mM}$ 2-mercaptoethanol and $0.175 \mathrm{ml}$ of $0.1 \mathrm{M}$ Tris-maleate buffer (at various $\mathrm{pH}$ values) containing $4 \mathrm{~mm} 2$-mercaptoethanol, at $37^{\circ} \mathrm{C}$ for $20 \mathrm{~min}$. Liberation of amino acid was measured with ninhydrin.

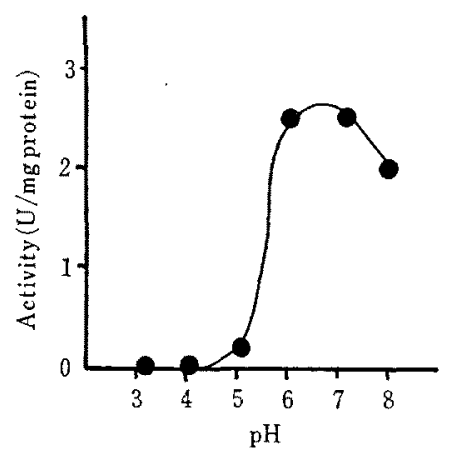

FIG. 9. Effect of pH on the Stability of the Enzyme.

The enzyme $(1.26 \mu \mathrm{g})$ in $0.025 \mathrm{ml}$ of $0.01 \mathrm{M}$ Tris $-\mathrm{HCl}$ buffer ( $\mathrm{pH} 7.2$ ) containing $4 \mathrm{~mm} 2$-mercaptoethanol was preincubated for $30 \mathrm{~min}$ with $0.025 \mathrm{ml}$ of $0.1 \mathrm{M}$ Macllvain buffer (at various $\mathrm{pH}$ values) containing $4 \mathrm{~mm} 2$-mercaptoethanol. $0.15 \mathrm{ml}$ of $0.3 \mathrm{M}$ Tris- $\mathrm{HCl}$ buffer (pH 7.2) containing $4 \mathrm{mM} 2$-mercaptoethanol and $0.2 \mathrm{ml}$ of $1 \mathrm{~mm} \mathrm{VVVA} \mathrm{in} 0.01 \mathrm{M}$ Tris-HCl buffer (pH 7.2) were added to the mixture. Incubation was performed at $37^{\circ} \mathrm{C}$ for $20 \mathrm{~min}$.

in Table II. The divalent ions used have an inhibitory effect.

\section{Effect of reagents}

Effect of some reagents was checked. As shown in Table III. EDTA and NEM have an inhibitory effect.

\section{Determination of the released amino acids}

Amino acids released from VVVA and AlaLeu-Gly-Ala-Leu-Gly during the incubation

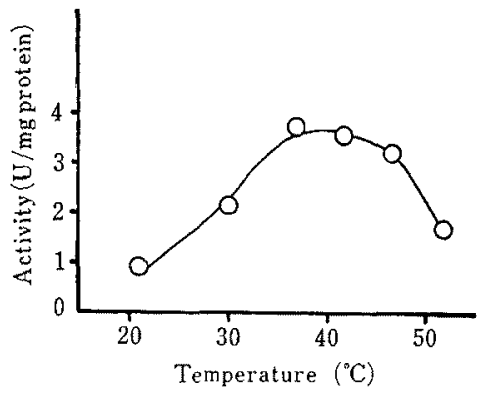

Fig. 10. Effect of Temperature on the Enzyme Activity.

The activities were measured using $1.26 \mu \mathrm{g}$ of the enzyme under the standard assay conditions at various temperatures.

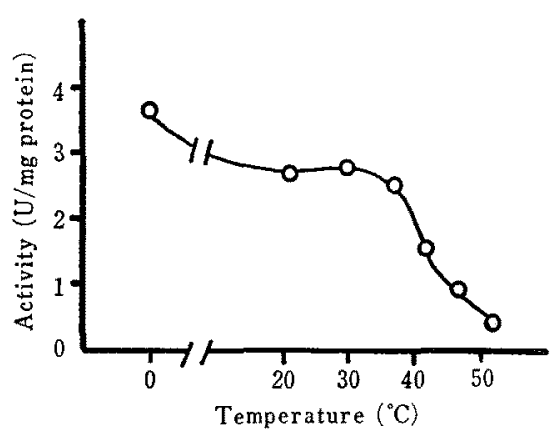

Frg. 11. Effect of Temperature on the Stability of the Enzyme.

After the enzyme $(1.26 \mu \mathrm{g}$ in $25 \mu \mathrm{l}$ of $0.01 \mathrm{M}$ Tris- $\mathrm{HCl}$ buffer (pH 7.2) containing $4 \mathrm{~mm} 2$-mercaptoethanol) had been preincubated for $30 \mathrm{~min}$ at various temperatures, the activity was assayed at $37^{\circ} \mathrm{C}$ under the standard assay conditions.

\section{Table II. EfFect of Metal Ions ON THE ENZYME ACTIVITY}

The enzyme $(1.26 \mu \mathrm{g})$ in $0.1 \mathrm{ml}$ of $0.01 \mathrm{M}$ Tris- $\mathrm{HCl}$ buffer (pH 7.2) containing $4 \mathrm{~mm}$ 2-mercaptoethanol was incubated with $0.2 \mathrm{ml}$ of $1 \mathrm{~mm}$ VVVA in $0.01 \mathrm{~m}$ Tris- $\mathrm{HCl}$ buffer $(\mathrm{pH} 7.2)$ and $0.1 \mathrm{ml}$ of various metal ions at $37^{\circ} \mathrm{C}$ for $20 \mathrm{~min}$.

\begin{tabular}{cc}
\hline Metal ion (final conc.) & Relative activity $(\%)$ \\
\hline $\mathrm{CaCl}_{2}(1 \mathrm{mM})$ & 31 \\
$\mathrm{MgCl}_{2}(1 \mathrm{mM})$ & 73 \\
$\mathrm{MnCl}_{2}(1 \mathrm{mM})$ & 38 \\
$\mathrm{ZnCl}_{2}(1 \mathrm{mM})$ & 2 \\
$\mathrm{CoCl}_{2}(1 \mathrm{mM})$ & 55 \\
$\left.\mathrm{~Pb}^{\mathrm{C}} \mathrm{CH}_{3} \mathrm{COO}\right)_{2}$ & 0 \\
$\mathrm{HgCl}_{2}(1 \mathrm{mM})$ & 0 \\
$\mathrm{CuSO}_{4}(1 \mathrm{mM})$ & 0 \\
None & 100 \\
\hline
\end{tabular}


Table III. Effect of Chemical Reagents ON THE ENZYME ACTIVITY

After the enzyme $(1.26 \mu \mathrm{g})$ in $0.1 \mathrm{ml}$ of $0.01 \mathrm{M}$ Tris- $\mathrm{HCl}$ buffer ( $\mathrm{pH} 7.2$ ) containing $4 \mathrm{~mm} 2$-mercaptoethanol had been preincubated with $0.1 \mathrm{ml}$ of various reagents at $37^{\circ} \mathrm{C}$ for $10 \mathrm{~min}, 0.2 \mathrm{ml}$ of $1 \mathrm{~mm} \mathrm{VVVA}$ in $0.01 \mathrm{M}$ Tris-HCl buffer ( $\mathrm{pH} 7.2$ ) was added. Incubation was performed at $37^{\circ} \mathrm{C}$ for $20 \mathrm{~min}$.

\begin{tabular}{|c|c|}
\hline Reagent (final conc.) & Relative activity $(\%)$ \\
\hline EDTA (1 mM) & 10 \\
\hline $\begin{array}{c}\text { O.Phenanthroline }{ }^{a)} \\
(0.75 \mathrm{~mm})\end{array}$ & 85 \\
\hline IAA $\quad(4 \mathrm{mM})$ & 84 \\
\hline NEM $\quad(0.75 \mathrm{~mm})$ & 60 \\
\hline $\mathrm{NEM}^{a)}(2.5 \mathrm{~mm})$ & 4 \\
\hline DTT (1mm) & 120 \\
\hline $\mathrm{NaN}_{3} \quad(1 \mathrm{~mm})$ & 124 \\
\hline None (Water) & 100 \\
\hline
\end{tabular}

with the enzyme at $\mathrm{pH} 7.2$ and $37^{\circ} \mathrm{C}$ were analyzed with a Hitachi Amino Acid Autoanalyzer (KLA-5) (Fig. 12), Only valine was liberated from VVVA. Alanine was first liberated and successively leucine from AlaLeu-Gly-Ala-Leu-Gly. Glycine was not de-

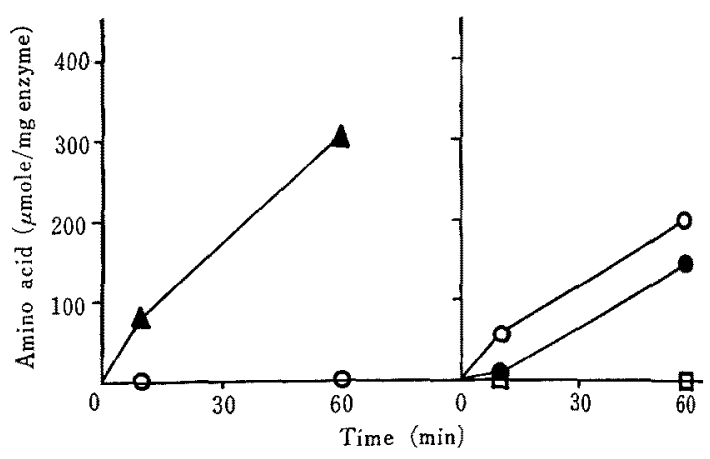

FIG. 12. Liberation of Amino Acids from VVVA (left) and Ala-Leu-Gly-Ala-Leu-Gly (right).

The enzyme was incubated with $0.5 \mathrm{~mm}$ peptide in $0.01 \mathrm{M}$ Tris- $\mathrm{HCl}$ buffer ( $\mathrm{pH} 7.2$ ) containing $2 \mathrm{~mm}$ 2-mercaptoethanol. Liberated amino acids were determined with a Hitachi Amino Acid Autoanalyzer (KLA-5). ○-O, Ala; • ๑, Leu; $\square-\square$, Gly; $\Delta-\mathbf{\Lambda}$, Val.

tected in this case.

\section{Specificity of the enzyme}

Table IV shows the relative rates of hydrolysis of various synthetic peptides by the enzyme, indicating that this is active on tri-, tetra-, penta- and hexapeptides, but not (or less active) on various dipeptides.

\section{Table IV. Relative Activity of the Enzyme for Various Peptides}

The rate of hydrolysis of VVVA is arbitrarily taken to be 1.00 . The final concentration of each substrate was $0.5 \mathrm{~mm}$.

\begin{tabular}{|c|c|c|c|}
\hline Peptide & $\begin{array}{l}\text { Relative } \\
\text { activity }\end{array}$ & Peptide & $\begin{array}{l}\text { Relative } \\
\text { activity }\end{array}$ \\
\hline Dipeptides & & Tetrapeptides & \\
\hline Gly $_{2}$ & 0.00 & $\mathrm{Val}_{4}$ & 0,98 \\
\hline $\mathrm{Val}_{2}$ & 0.00 & VVVA & 1.00 \\
\hline Ile-Gly & 0.02 & Gly -Gly-Ile-Ala & 0.00 \\
\hline Leu-Gly & 0.00 & Lys-Gly-Ile-Ala & 1.15 \\
\hline Val-Gly & 0.01 & Thr-Gly-Ile-Ala & 0.10 \\
\hline His. Gly & 0,00 & Ile-Gly-Ile-Ala & 0.19 \\
\hline Ser-Gly & 0.04 & Glu-Gly-Ile-Ala & 0.92 \\
\hline Phe-Gly & 0.05 & D-Ala-Gly-Ile-Ala & 0.00 \\
\hline Thr-Gly & 0.00 & Ala-Gly-Phe-Ala & 1.94 \\
\hline Tyr-Gly & 0.00 & Met-Gly-Phe-Ala & 1.76 \\
\hline Met-Gly & 0.00 & Val-Gly-Phe-Ala & 0.31 \\
\hline Z-Gly-Phe & 0.00 & Pentapeptide & \\
\hline Tripeptides & & $\mathrm{Val}_{5}$ & 0.24 \\
\hline Val-Tyr-Val & 0.66 & Hexapeptide & \\
\hline $\mathrm{Val}_{3}$ & 0.57 & Ala-Leu-Gly-Ala-Leu-Gly & 1.17 \\
\hline Gly $_{3}$ & 0.00 & & \\
\hline Gly-Leu-Tyr & 0.00 & & \\
\hline
\end{tabular}




\section{DISCUSSION}

We have been studying on the proteolysis in the skeletal muscle, ${ }^{1 \sim 3)}$ and found that there was a proteolytic system active in a neutral $\mathrm{pH}$ region besides the one active in an acidic region. ${ }^{3)}$ We also found that there were various enzymes as members of this proteolytic system in a neutral $\mathrm{pH}$ region (unpublished). There are many kinds of work on the acidic proteolytic system composed of cathepsins, ${ }^{12}$ ) but only a few reports have been presented as to the neutral proteolytic system in tissues. ${ }^{13)}$ On the other hand, the mechanism of protein degradation in vivo has not been clarified yet. Furthermore, it is considered that the major product formed by the proteinase action are large oligopeptides. ${ }^{14)}$ There are, however, also a few reports on the oligopeptidases ${ }^{5 \sim 7}$ ) that hydrolyze larger oligopeptides than tripeptide and on the mechanism of their hydrolysys in tissues. Therefore, it may be important to study the oligopeptidase active in a neutral $\mathrm{pH}$ region.

It is considered that the ammonium sulfate precipitate fraction contains various kinds of peptidases. The high total VVVA hydrolytic activity of the ammonium sulfate precipitate fraction might be explained from the cooperative action of these peptidases. Separation of each enzyme by DEAE-cellulose column chromatography might result in the low recovery of the VVVA hydrolytic activity.

Figure 4 shows three peaks of the activity. In a preliminary investigation, however, only one peak was detected where the elution was made with the gradient in a range of $0.001 \mathrm{M}$ to $0.2 \mathrm{M}$. The enzyme activity was lost in the process of the gradient elution, because the time required in this method was too long to keep its activity. Therefore, the step-wise elution was made in a shorter period of time. It was thus successful to obtain fractions with high activity (Fig. 4).

In the case of the polyacrylamide gel disc electrophoresis, 2-mercaptoethanol was added at a final concentration of $4 \mathrm{~mm}$ to the gel in order to recover the full enzyme activity.
Riboflavin was used as the catalyst for polymerization of acrylamide, because it was disclosed that there was a problem of the unexpected formation of some artifacts from ammonium persulfate in the case of $\mathrm{SH}$ protease. $^{15\rangle}$

Inhibition of the enzyme by EDTA suggests that metal ion is essential to the activity. The divalent ions tested here affected the enzyme activity (Table II). The enzyme was also inhibited by NEM, and lost the activity when buffer containing no 2-mercaptoethanol was used. These results show that the SH-group is essential to the activity.

The results in Fig. 12 show that the enzyme splits off the amino-terminal amino acid from each peptide. The enzyme was, therefore, found to be an aminopeptidase. This muscle aminopeptidase shows specificity for tripeptides and larger oligopeptides (Table IV). It is considered that the muscle aminopeptidase is inactive (or less active) on the oligopeptides having glycine at the amino-terminal (Fig. 12 and Table IV). The results in Table IV also suggest that the muscle aminopeptidase prefers a straight-chain amino-terminal amino acid rather than a branched one.

There are many reports ${ }^{16)}$ on aminopeptidases. The cytosol aminopeptidase ${ }^{17)}$ (EC 3.4.11.1) formerly called leucine aminopeptidase hydrolyzes Leu-Gly, and is activated by $\mathrm{Mn}^{2+}$ and $\mathrm{Mg}^{2+}$. The microsomal aminopeptidase $^{18)}$ (EC 3.4.11.2) hydrolyzes the peptide having glycine at its amino-terminal, and is not affected by EDTA. These observations suggest that the muscle aminopeptidase presently studied differs from these aminopeptidases.

Proteolysis proceeds in the post mortem aging of meat and amounts of amino acids increase as a result of this proteolysis, ${ }^{19}$ ) although the mechanism is not yet known in detail. The enzyme reported here hydrolyzes oligopeptides to amino acids, and is stable at pH 6.1. These results may suggest that this enzyme brings forth the production of amino acids during the post mortem aging and contributes to the taste of meat. 
Acknowledgement. We wish to thank Dr. S. Arai, University of Tokyo, for his valuable discussions. We also thank Ms. Y. Nakayama, Gunma University, for her technical support.

\section{REFERENCES}

1) A. Okitani, K. Shinohara, M. Sugitani and M. Fujimaki, Agr. Biol. Chem., 37, 321 (1973).

2) A. Okitani and M. Fujimaki, ibid., 36, 1265 (1972).

3) A. Okitani, Y. Otsuka, M. Sugitani and M. Fujimaki, ibid., 38, 573 (1974).

4) T. Linderg, O. Noren and H. Sjostrom, "Peptide Transport in Protein Nutrition," ed. by D. M. Mattews and J. W. Payne, North-holland, Netherlands, 1975, p. 204.

5) S. Ellis and M. Perry, J. Biol. Chem., 241, 3679 (1966).

6) S. Auricchio, M. Pierro and M. Orsatti, Anal. Biochem., 39, 15, (1971).

7) J. Donlon and P. F. Fottrell, Comp. Biochem. Physiol., 41B, 181 (1972).

8) R. Katakai, J. Org. Chem., 30, 2699 (1975).

9) E. Cocking and E. W. Yemm, Biochem. J., 58, 12 (1954).

10) E Layne, "Methods in Enzymology," Vol. 3, ed. by S. P. Colowick and N. O. Kaplan, Academic Press, New York, N.Y., 1957, p. 452.

11) B. J. Davis, Ann. New York Acad. Sci., 121, Art 2, 404 (1964).

12) "Tissue Proteinase," ed. by A. J. Barrett and J. T. Dingle, North-Holland, Netherland, 1971.

13) R. T. Schimke, "Intracellular Protein Turnover," ed. by R. T. Schimke and N. Katsunuma, Academic Press, New York, 1975, p. 173.

14) C. Nolan, W. B. Novoa, E. G. Krebs and E. H. Fischer, Biochemistry, 3, 542 (1964).

15) W. M. Mitchell, Biochim. Biophys. Acta, 147, 171 (1967).

16) "Enzyme Nomenclature," Recommendations (1972) of the International Union of Pure and Applied Chemistry and the International Union of Biochemistry, Elsevier, Amsterdam, The Netherlands, 1973, p. 232.

17) R. J. Delange and E. L. Smith, "The Enzymes," $3 r d$ ed., Vol. III, ed. by P. D. Boyer, Academic Press Inc., New York, N.Y., 1971, pp. 82 102.

18) G. Pfieiderer, P. G. Celliers, M. Stanulovic, E. D. Wachsmuth, H. Determann and G. Braunitzer, Biochem. Z., 340, 552 (1964).

19) A. Suzuki, M. Nakazato and M. Fujimaki, Agr. Biol. Chem., 31, 953 (1967). 